\title{
Thermal Annealing Surface Modification: Effect on Surface and Performance of Electrospun Nylon 6,6 Nanofiber Membrane for Wastewater Treatment
}

\author{
${ }^{1}$ Muhammad Amir Nasrin Mohd Asri, ${ }^{1}$ Nur Syakinah Abd Halim, ${ }^{1 *}$ Mohd Dzul \\ Hakim Wirzal, ${ }^{2}$ Abdull Rahim Mohd Yusoff, ${ }^{3}$ Muhammad Roil Bilad \\ ${ }^{1}$ Chemical Engineering Department, Universiti Teknologi PETRONAS, Bandar Seri Iskandar, Perak, \\ 32610, Malaysia. \\ ${ }^{2}$ Faculty of Science, Universiti Teknologi Malaysia, Skudai, 81310, Malaysia. \\ ${ }^{3}$ Faculty of Science, Engineering and Applied Science, Universitas Pendidikan Mandalika, Jl. Pemuda \\ No. 59A, Mataram, 83126, Indonesia. \\ *Corresponding author email: mdzulhakim.wirzal@utp.edu.my
}

Received: 10 March 2021; Revised: 22 March 2021; Published: 30 March 2021

\begin{abstract}
As the forefront in fiber materials development, electrospun nanofiber membrane (NFM) is potentially reliable for wastewater treatment due to its excellent properties for instance; large surface area, high porosity, tuneable pore size, and has great flux as compared to other conventional membranes. However, fouling issue will lead to degradation of membrane performance. Fouling issue can be alleviated by applying membrane surface modification. In this study, thermal annealing is applied onto nylon 6,6 nanofiber membrane with three different temperatures $\left(60^{\circ} \mathrm{C}, 80^{\circ} \mathrm{C}\right.$ and $\left.120^{\circ} \mathrm{C}\right)$. Results show that annealing causes membrane shrinkage and reduction of membrane fiber diameter where the fiber reduced from $138.5 \mathrm{~nm}$ to $108.5 \mathrm{~nm}$ when annealed at $120^{\circ} \mathrm{C}$. The optimum annealing temperature for the membrane was found to be at $60^{\circ} \mathrm{C}$ as the membrane shows the highest flux at $1200 \mathrm{~L} / \mathrm{m}^{2} . \mathrm{h}$ at 75 minutes filtration time and took longer time to get fouled ( $>75$ minutes) compared with un-annealed membrane (55 minutes). Nylon 6,6 nanofiber membrane is also proven to give more than $90 \%$ of COD and turbidity rejection.
\end{abstract}

Keywords: thermal annealing; nanofiber membrane; wastewater

How to Cite: Mohd Asri, M., A., N., Abd Halim, N., S., Wirzal, M., D., H., Mohd Yusoff, A., R., \& Bilad, M., R. (2021). Thermal Annealing Surface Modification: Effect on Surface and Performance of Electrospun Nylon 6,6 Nanofiber Membrane for Wastewater Treatment. Jurnal Penelitian dan Pengkajian Ilmu Pendidikan: e-Saintika, 5(1), 56-66. doi:https:// doi.org/10.36312/e-saintika.v5i1.395

\section{INTRODUCTION}

Nowadays, the wastewater treatment has become more challenging due to the stringent limit for wastewater discharge into the water bodies. Clean water is highly demanded which requires more wastewater to be treated (Sun, Bai, Jiayu, Zhiwei, \& Fuyi, 2017). Therefore, a more reliable technology is needed for excellent wastewater treatment. Membrane technology is one of the advanced methods for wastewater treatment due to its stable effluent quality, small footprint and low energy consumption (Azizo, Wirzal, Bilad, \& Yusoff, 2017; Ibrahim, Wirzal, Nordin, \& Halim, 
2018). Moreover, particles with sizes less than $<10 \mu \mathrm{m}$ can be removed as the membrane pore size can be tuned into sub-micron size (Abd Halim et al., 2021).

The application of nanofiber membrane (NFM) has been extensively studied for wastewater treatment due to its porous structure, huge surface area, great flux with small fiber diameter and has low production cost (Abd Halim et al., 2021; Bilad et al., 2018; Foong, Wirzal, \& Bustam, 2019; Jiřiček, Komárek, \& Lederer, 2017; Saad, Balasubramaniam, et al., 2020; Saad, Wirzal, Abd Halim, \& Khar, 2020).

However, membrane technology are prone to fouling issue which leads to membrane permeation flux reduction (Ibrahim et al., 2018; J. Zhang et al., 2015). Fouling causes membrane blockage through particle deposition on a membrane surface or in membrane pores. Besides that, particles can easily entrap inside the multi-layered mat causes internal fouling. Thus, membrane productivity will be lower besides having a higher cost for membrane cleaning and replacement (Benito, Garcia, \& Gonzalez-Olmos, 2017; Eliseus, Bilad, Nordin, Putra, \& Wirzal, 2017).

To treat this problem, membrane surface modification can be applied where it will enhance the membrane performance by altering the membrane surface properties (Abd Halim et al., 2021; Mat Nawi et al., 2020; Mohd et al., 2020). Furthermore, the characteristic surface of a membrane plays an important role in controlling fluid separation during membrane filtration process. There are several membrane surface modification methods can be applied such as coating, heat-pressed treatment, thermal annealing and solvent vapor treatment (Abd Halim et al., 2021; Mat Nawi et al., 2020).

Ideally, annealing treatment with suitable conditions may be more environment friendly compared with the other surface modification methods ( $\mathrm{Li}$, Hashaikeh, \& Arafat, 2013). Annealing can be conducted by drying a membrane inside an oven at different temperature. Several research show that annealing will make an impact on surface morphology of membrane and able to enhance membrane performance and mechanical strength. Zhang et al. (2012) studied two types of heating methods which are relaxed heating and tension heating (L. Zhang et al., 2012). It is found that relaxed heating causes fiber shrinkage while tension heating reduces fiber diameter through stretching and rearrangement of the molecular chains along the direction of the external force. Besides, Li et.al. (2013) conducted thermal annealing on poly (lactic acid) nanofiber membrane at different annealing temperatures. The results shows that the annealed membrane has the highest solid rejection $(\sim 85 \%)$ and the Young's modulus improved remarkably by about $2500 \%$ (Li et al., 2013).

Previous study on nylon 6,6 NFM surface modification was conducted by Abd Halim et.al (2019), where they applied solvent vapor treatment (formic acid exposure) onto nylon 6,6 NFM for produced water filtration (Abd Halim, Wirzal, Bilad, Md Nordin, Adi Putra, Sambudi, et al., 2019). It is found that 5 hours is the optimum treatment time with $100 \%$ of oil removal and the treated NFM has permeability almost similar to the untreated one $\left(733 \mathrm{~L} / \mathrm{m}^{2}\right.$.h.bar). Besides that, another study on the modification of nylon 6,6 NFM was conducted by blending the membrane with ZIF-8 nanoparticles for produced water treatment (Abd Halim, Wirzal, Bilad, Md Nordin, Adi Putra, Mohd Yusoff, et al., 2019). It is found that nylon 6,6 NFM modified with $0.2 \%$ ZIF-8 has the greatest steady-state pure water permeability $\left(1967 \mathrm{~L} /\left(\mathrm{m}^{2} \cdot \mathrm{h} \cdot \mathrm{bar}\right)\right.$, twice higher than untreated one with $89 \%$ of oil removal. 
In this article, we will investigate the effect of thermal annealing onto nylon 6,6 NFM where the performance of filtration between untreated and treated membrane will be evaluated based on flux, COD and turbidity rejection. To our best knowledge, thermal annealing has not been applied yet onto nylon 6,6 NFM for wastewater filtration. This study will give us a more insight on how heat treatment/annealing, a simple yet more accessible method with no chemicals involved, can affect NFM surface properties and performance.

\section{METHOD}

\section{Membrane Solution Preparation}

$14 \mathrm{wt} \%$ of nylon 6,6 pellets (Sigma Aldrich) were dissolved in a mixture of formic acid (98-100\%, MERCK) and acetic acid (99.85\%, VWR Chemicals) with 1:1 ratio. The solution was stirred overnight until homogeneous solution is achieved.

\section{Electrospinning Process}

Electrospinning equipment, which comprises of a syringe pump attached with metallic needle, a high-voltage power supply and a rotating drum collector was used. Figure 1 shows the overall setup of the equipment. The voltage was set at $26 \mathrm{kV}$ and the flow rate of the polymer solution ejected from the syringe was set at $0.4 \mathrm{~mL} / \mathrm{h}$. The rotator controller was set 500 RPM with the distance between the tip of the needle and the collector was kept at $15 \mathrm{~cm}$.

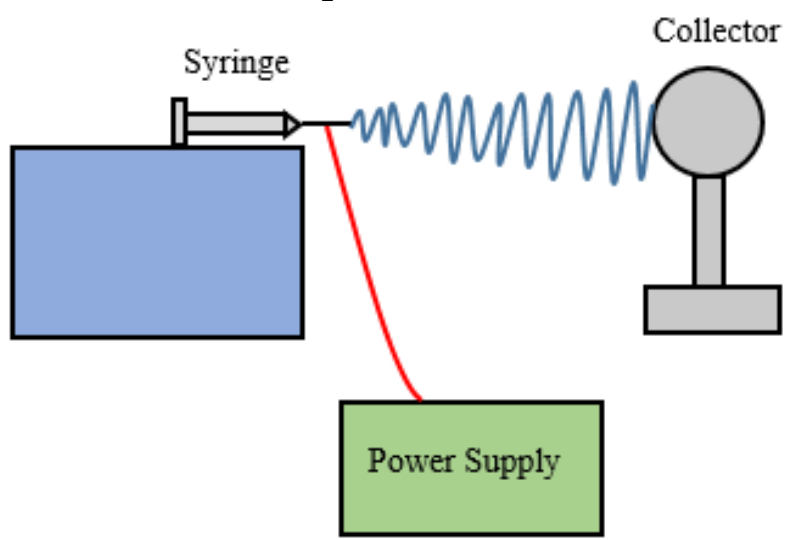

Figure 1. A schematic diagram of electrospinning setup.

\section{Membrane Annealing}

The membrane was cut into small pieces of samples. The membrane was then thermally annealed in the air oven at three different temperatures which are $60^{\circ} \mathrm{C}$, $80^{\circ} \mathrm{C}$ and $120^{\circ} \mathrm{C}$ for 30 minutes and later was labelled as T60, T80 and T120.

\section{Membrane Characterization}

For membrane characterization, it was divided into few sections which are surface morphology, porosity, surface roughness and contact angle. Surface morphology of the NFMs were observed by using Field Emission Scanning Electron Microscopy (FESEM, Model: VPFESEM, Zeiss Supra55 VP, Feldbach, Switzerland) with up to 10,000 pixel (px) of magnification. The membrane was cut into smaller size $(1.5 \mathrm{~cm} \times 0.5 \mathrm{~cm})$ and mounted on metal substrate using carbon tape and coated with thin layer of gold. All the images later were analyzed by using ImageJ software to find the average pore size and fiber diameter. The porosity was measured by using dry 
wet method. Micrometer gauge was used to measure the membrane thickness. Equation 1 represents the overall formula for porosity.

$$
\text { Porosity }=\frac{V_{\text {water }}}{V_{\text {membrane }}} \times 100
$$

where, $V_{\text {water }}$ is volume of water and $V_{\text {membrane }}$ is the overall membrane volume.

Membrane surface roughness measurement was conducted first by cutting the membrane with dimension of $1.5 \mathrm{~cm} \times 0.5 \mathrm{~cm}$ and analyzed by using Atomic Force Microscopy (AFM, Model: NanoNavi E-Sweep Anton Paar, GmbH, Graz Austria) in contact mode. The membrane was analyzed with area of 10,000 $\mathrm{nm}^{2}$. Membrane hydrophilicity was measured by using goniometer (IFT, Model: OCA 20, Data Physics, Filderstadt, Germany). Sessile drop method was chosen as the experiment setup method. The reading was taken over time for 5 seconds with repetition three times for each membrane.

\section{Membrane Filtration}

Membrane filtration was conducted based on wastewater flux. The wastewater used was taken from secondary wastewater treatment unit in Universiti Teknologi PETRONAS sewage plant. The overall experimental setup can be seen in Figure 2. The membrane was cut in circular shape with the diameter of $5.7 \mathrm{~cm}$. The flow rate was fixed at $80 \mathrm{~L} / \mathrm{h}$. Equation 2 was used to determine the flux. The operating pressure was set at 1 bar and conducted in 75 minutes filtration time. For cleaning purpose, the membrane was immersed into 2000 ppm sodium hypochlorite solution $(\mathrm{NaClO})$ for 1 hour after the filtration was completed. The filtration process was repeated three times to measure membrane reproducibility.

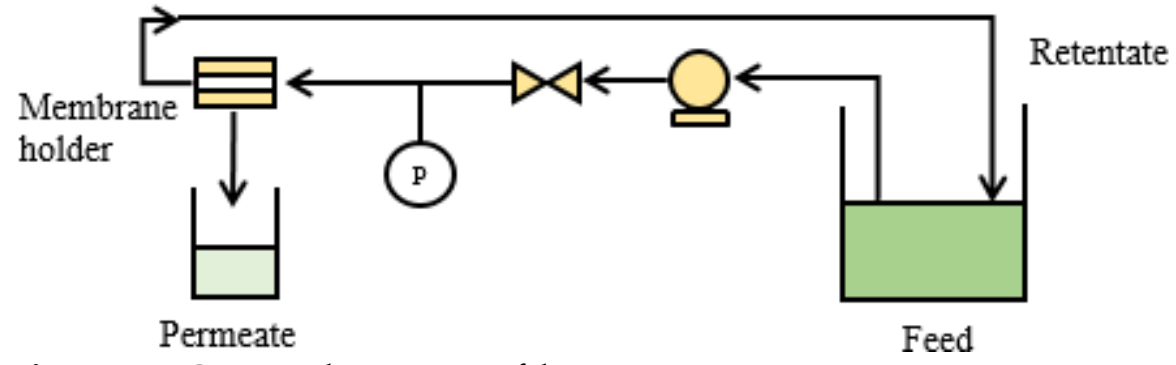

Figure 2. Cross-Flow Microfiltration Unit

$$
J=\frac{V}{A t}\left(\mathrm{~L} / \mathrm{m}^{2} \mathrm{~h}\right)
$$

where $\mathrm{V}$ is volume $(\mathrm{L}), \mathrm{A}$ is area $\left(\mathrm{m}^{2}\right)$ and $\mathrm{t}$ is time $(\mathrm{h})$.

\section{Rejection Analysis}

Membrane rejection analysis was based on chemical oxygen demand (COD) and turbidity measurement before and after filtration. The COD was measured by using 2 $\mathrm{mL}$ Low Range (LR) COD tubes and the sample was heated in the COD reactor at $150^{\circ} \mathrm{C}$ for 2 hours to ensure complete digestion. Equation 3 was used to estimate the rejection. The samples were measured using UV-VIS Spectrophotometer (Model: DR 5000 Spectrophotometer, Hach Company, Loveland, Colorado, United States), Hach- 
Lange kits for COD, and turbidity meter (Model: 2100Q Portable Turbidimeter, Hach Company, Loveland, Colorado, United States), respectively.

$$
\operatorname{COD} \% \text { rejection }=\left(1-\frac{C_{f}}{C_{0}}\right) \times 100
$$

where, $\mathrm{C}_{\mathrm{o}}$ is $\mathrm{COD}$ before filtration and $\mathrm{C}_{\mathrm{f}}$ is $\mathrm{COD}$ after filtration.

\section{RESULTS AND DISCUSSION}

\section{Membrane Characterization}

Figure 3 shows the FESEM images for modified electrospun nylon 6,6 NFMs via thermal annealing at temperature of $60^{\circ} \mathrm{C}, 80^{\circ} \mathrm{C}$ and $120^{\circ} \mathrm{C}$. In a glance, no obvious changes were observed with respect to non-annealed NFM. However, the results were more profound for pore size and membrane fiber diameter. In comparison, the straight fiber $\left(\mathrm{T}=0^{\circ} \mathrm{C}\right)$ wrinkled a bit with fiber diameter reduction between the temperatures of $60^{\circ} \mathrm{C}$ to $120^{\circ} \mathrm{C}$ as can be seen in Table 1 . The shrinkage of fibers occur (the straight fiber became wrinkled) because the entanglement crosslink between the fibers were restrained (Lu Zhang, Liu, Pan, Wang, \& Pan, 2012). Apart from that, membrane shrinkage could occur since the fibers were thermally annealed above the glass transition temperature $\left(\mathrm{T}_{\mathrm{g}}\right)$ of nylon $6,6\left(\mathrm{~T}_{\mathrm{g}}=50^{\circ} \mathrm{C}\right.$ to $\left.60^{\circ} \mathrm{C}\right)$. $\mathrm{T}_{\mathrm{g}}$ can be described as the temperature range which allows the polymer to transform from a rigid glassy material to a soft, un-melted material. Above this temperature, a non-restricted motion of polymer chains allow rearrangement of membrane molecules (Chen, Deng, Liu, \& Songc, 2017; Kusworo, Aryanti, Firdaus, \& Sukmawati, 2015; Wang et al., 2014).

Apart from membrane shrinkage, annealing also causes reduction of fiber diameter with increasing treatment temperature as can be seen in Table 1 . It was reported by Tan et.al. (2006), which stated that annealed fibers are thinner than unannealed fibers, due to more closely-packed crystallites formed by amorphous chains rearrangement (Tan \& Lim, 2006). Furthermore, the reduction of membrane fiber diameter causes the mean pore size of NFM to become larger, hence affecting the porosity of NFM in which it increases as the temperature increases.

Besides that, it is found that surface roughness increases as temperature increases (Table 1) which indicate that rougher surface can be obtained when annealing is applied. This is due to membrane shrinkage phenomena where it causes the fibers to be wrinkled, hence producing uneven surface. This is as explained by Zhang et.al. (2012), as the membrane is in relaxation state, membrane shrinkage will occur as the molecular chain tends to be in stable state with minimum energy, however, the shrunk fiber will become curve at the same time as there is restrain of the entanglement crosslink between fibers (Lu Zhang et al., 2012). 
$3,000 \mathrm{px}$

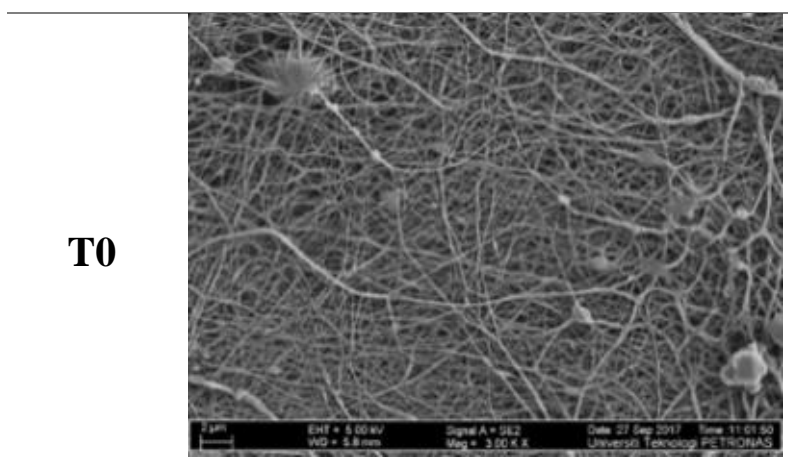

T60

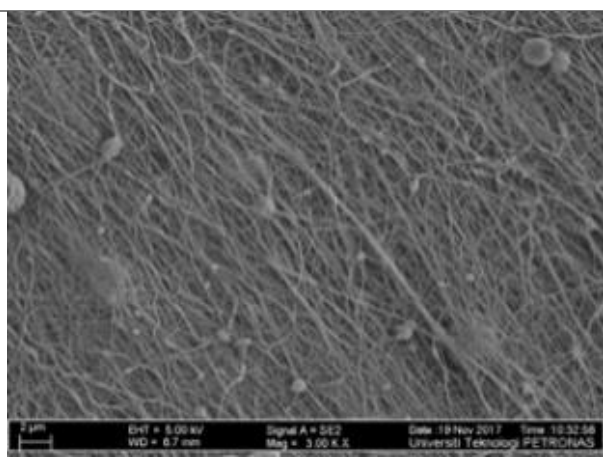

T80

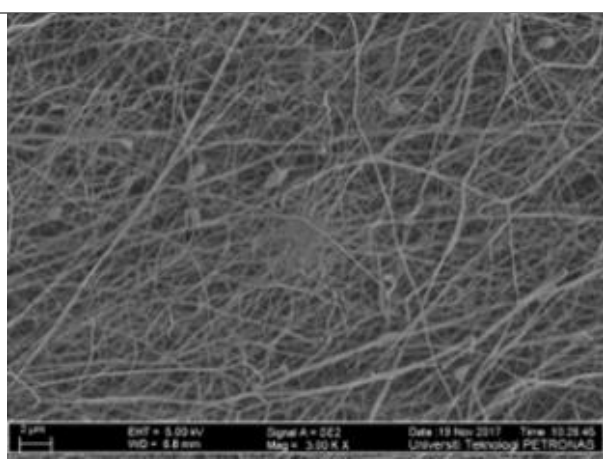

T120

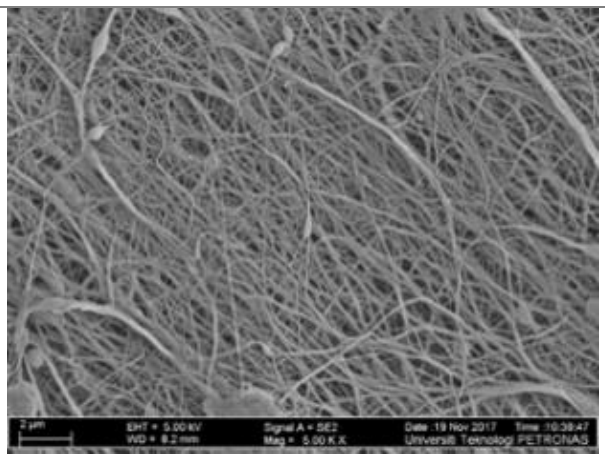

10,000 px
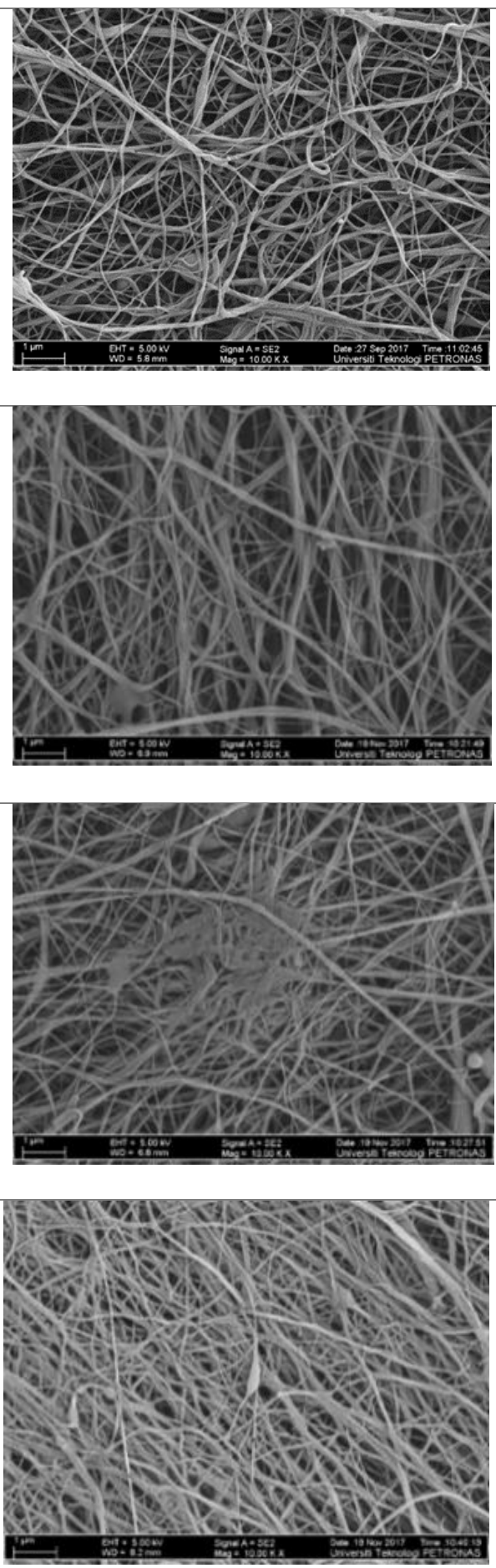

Figure 3. Membrane surface morphology for T0, T60 and T80 and T120 NFMs. 
Table 1. Membrane properties of T0, T60 and T80 and T120 NFMs.

\begin{tabular}{cccccc}
\hline $\begin{array}{c}\text { Treatment } \\
\text { temperature } \\
\left({ }^{\circ} \mathbf{C}\right)\end{array}$ & $\begin{array}{c}\text { Sample } \\
\text { Name }\end{array}$ & $\begin{array}{c}\text { Porosity } \\
(\mathbf{\%})\end{array}$ & $\begin{array}{c}\text { Mean } \\
\text { Pore Size } \\
(\boldsymbol{\mu m})\end{array}$ & $\begin{array}{c}\text { Membrane } \\
\text { Diameter } \\
(\mathbf{n m})\end{array}$ & $\begin{array}{c}\text { Surface } \\
\text { Roughness, } \\
\text { RMS (nm) }\end{array}$ \\
\hline 0 & $\mathrm{~T} 0$ & $70 \pm 2$ & 0.050 & $138.5 \pm 54$ & 238.2 \\
60 & $\mathrm{~T} 60$ & $73 \pm 13$ & 0.057 & $133 \pm 72$ & 275.7 \\
80 & $\mathrm{~T} 80$ & $77 \pm 15$ & 0.067 & $128 \pm 54$ & 280.9 \\
120 & $\mathrm{~T} 120$ & $80 \pm 9$ & 0.072 & $108.5 \pm 49.5$ & 426.3 \\
\hline
\end{tabular}

Water contact angle vs time for untreated and treated nylon 6,6 NFM with treatment temperature of $60^{\circ} \mathrm{C}, 80^{\circ} \mathrm{C}$ and $120^{\circ} \mathrm{C}$ is represented in Figure 4 . From the graph, it is found that as the annealing temperature increases, the water contact angle increases, producing less hydrophilic membrane. T0 has the lowest water contact angle which is around $34^{\circ}$ compared to the T120 which is around $48^{\circ}$. This is due to increase in membrane surface roughness which resulted in more wrinkled membrane. This could happened because surface wettability is affected by membrane surface roughness where smoother surface will have lower water contact angle compared to a rougher surface (Abd Halim, Wirzal, Bilad, Md Nordin, Adi Putra, Mohd Yusoff, et al., 2019; Abd Halim, Wirzal, Bilad, Md Nordin, Adi Putra, Sambudi, et al., 2019; Ahmad, Leo, Ahmad, \& Ramli, 2015).

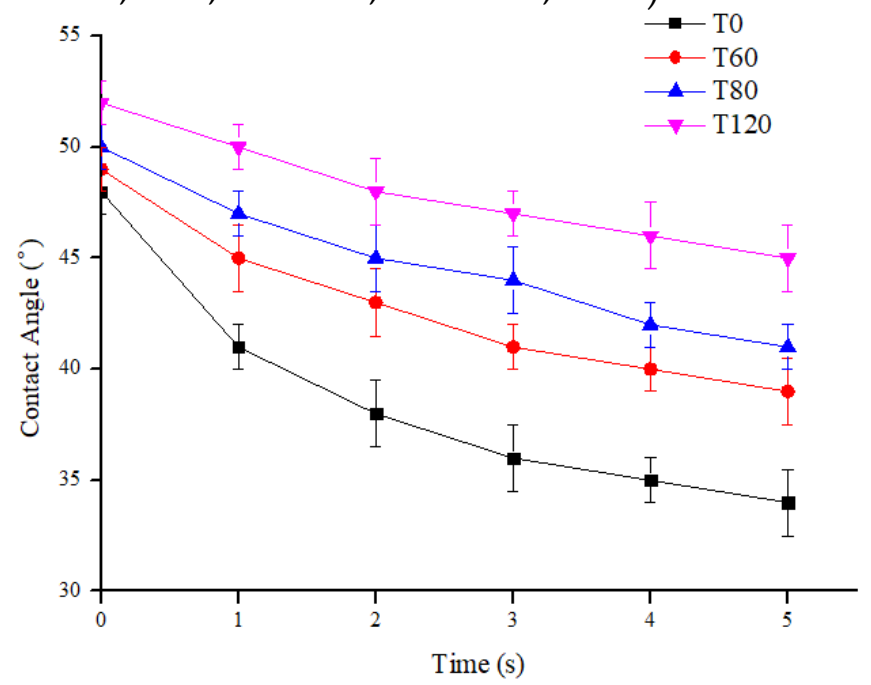

Figure 4. Contact angle vs time for T0, T60 and T80 and T120 NFMs.

\section{Permeability Analysis}

Based on Figure 5, NFM treated at $60^{\circ} \mathrm{C}$ shows the highest flux $\left(1200 \mathrm{~L} / \mathrm{m}^{2} . \mathrm{h}\right)$ compared to untreated nylon 6,6 NFM $\left(980 \mathrm{~L} / \mathrm{m}^{2}\right.$.h) at 75 minutes filtration time. As the annealing temperature increases, the permeability also increases. As compare to T80 and T120, T60 NFM is believed to face membrane shrinkage (wrinkle) only at the upper/first layer of the membrane. This phenomenon causes an opening layer at the membrane, hence enable water to pass through easily (Abtahi et al., 2019). However, as the temperature increases to $80^{\circ} \mathrm{C}$, the fibers wrinkles at all parts of membrane layers, hence making it harder for the water to pass through. In other words, the membrane tortuosity increases. Moreover, huge flux reduction also occurs at T80 and T120 NFMs due to membrane fouling. The wrinkled fibers cause the membrane surface to be uneven. Membrane fouling is often associated with uneven membrane 
surface (AFM results for T80 and T120 membrane surface roughness are $280.9 \mathrm{~nm}$ and $426.3 \mathrm{~nm}$ respectively). From here, it can be conclude that, thermal annealing can help to improve the performance of the membrane by increasing the permeability and also reducing fouling but only up to certain temperature (Hemra, Kitiwan, \& Atong, 2011).

Apart from that, T60 NFM does not achieve steady state condition at 75 minutes filtration time as compared with the other membranes. The greater water uptake at the initial permeability causes the membrane to take more time to achieve steady-state (Abd Halim, Wirzal, Bilad, Md Nordin, Adi Putra, Mohd Yusoff, et al., 2019). This indicates that thermal annealing able to slow down the time taken for the membrane to get fouled, in other words, annealing will help to reduce fouling.

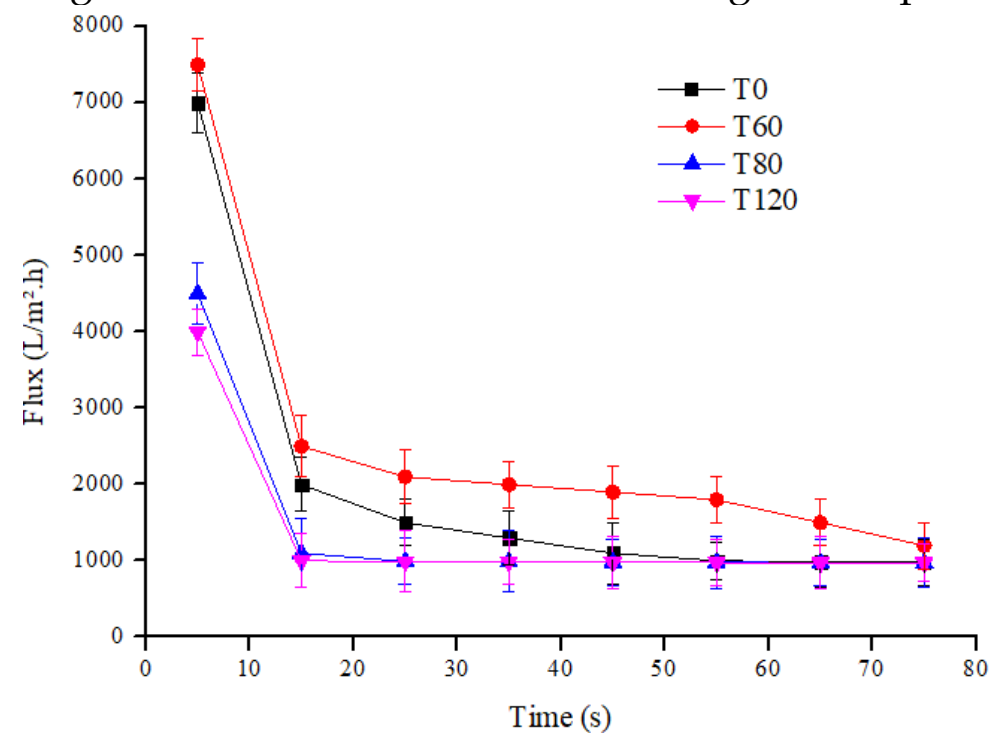

Figure 5. Wastewater flux for T0, T60 and T80 and T120 NFMs with condition of pressure at 1 bar and flow rate at $80 \mathrm{~L} / \mathrm{h}$ for 75 minutes filtration time.

\section{Rejection Analysis}

Based on the rejection analysis shown in Table 2, all nylon 6,6 NFMs able to achieve excellent COD rejection and exceptional decrease in turbidity. This result correlates with the standard COD rejection of NFM where it has more than $90 \%$ rejection (Balamurugan, Sundarrajan, \& Ramakrishna, 2011). Besides that, all treated NFM also able to achieve $>90 \%$ turbidity removal. This results were attributed by the hydrophilicity of nylon 6,6 NFM where it attracts more water molecules to pass through the membrane hence able to reject unwanted solid particles (Abd Halim, Wirzal, Bilad, Md Nordin, Adi Putra, Mohd Yusoff, et al., 2019; Abd Halim, Wirzal, Bilad, Md Nordin, Adi Putra, Sambudi, et al., 2019).

Table 2. COD and turbidity rejection for T0, T60, T80 and T120 NFMs.

\begin{tabular}{ccc}
\hline Sample Name & COD rejection (\%) & Turbidity (NTU) \\
\hline Wastewater & - & $4-7$ \\
T0 & 91.50 & 0.42 \\
T60 & 92.30 & 0.28 \\
T80 & 92.32 & 0.29 \\
T120 & 93.10 & 0.28 \\
\hline
\end{tabular}




\section{CONCLUSION}

In this study, the effect of thermal annealing on membrane properties of nylon 6,6 NFM has been studied. Based on the results obtained, the porosity of the membranes shows an increasing trend when compared between untreated and treated membrane. This is due to heating effect which causes membrane shrinkage, hence increases overall porosity. The membrane shrinkage also increases membrane surface roughness and reduces membrane hydrophilicity. However, based on filtration test, it shows that the membrane with heat treated temperature of $60^{\circ} \mathrm{C}$ has the highest flux $\left(1200 \mathrm{~L} / \mathrm{m}^{2} . \mathrm{h}\right)$ at 75 minutes filtration time. The membrane also able to achieve excellent COD and turbidity rejection (>90\%). The optimum annealing temperature for the membrane was found to be at $60^{\circ} \mathrm{C}$ as the membrane show higher flux and took longer time to get fouled ( $>75$ minutes) which increase the membrane overall productivity.

\section{RECOMMENDATION}

Further characterization such as mechanical strength can be conducted to study the effect of thermal annealing on NFM mechanical strength. Besides that, different pressure for permeability test can be applied to observe the difference in membrane performance when high hydraulic pressure is applied. Lastly, different type of wastewater can be used so that it can be further proven that modified nylon 6,6 NFM is practical to be used for treatment of heavy-duty waste.

\section{ACKNOWLEDGMENT}

We would like to thank Yayasan Universiti Teknologi PETRONAS for providing research grant (YUTP: 015 LC0-248) to carry out research activities.

\section{REFERENCES}

Abd Halim, N. S., Wirzal, M. D. H., Bilad, M. R., Md Nordin, N. A. H., Adi Putra, Z., Mohd Yusoff, A. R., ... Faungnawakij, K. (2019). Electrospun Nylon 6,6/ZIF-8 Nanofiber Membrane for Produced Water Filtration. Water, 11(10), 2111. https://doi.org/10.3390/w11102111

Abd Halim, N. S., Wirzal, M. D. H., Bilad, M. R., Md Nordin, N. A. H., Adi Putra, Z., Sambudi, N. S., \& Mohd Yusoff, A. R. (2019). Improving Performance of Electrospun Nylon 6,6 Nanofiber Membrane for Produced Water Filtration via $\begin{array}{llll}\text { Solvent Vapor } & \text { Treatment. } & \text { Polymers, } & \text { 112). }\end{array}$ https://doi.org/10.3390/polym11122117

Abd Halim, N. S., Wirzal, M. D. H., Hizam, S. M., Bilad, M. R., Nordin, N. A. H. M., Sambudi, N. S., ... Yusoff, A. R. M. (2021). Recent Development on Electrospun Nanofiber Membrane for Produced Water Treatment: A review. Journal of Environmental Chemical Engineering, 9(1), 104613. https:// doi.org/10.1016/j.jece.2020.104613

Abtahi, S. M., Marbelia, L., Gebreyohannes, A. Y., Ahmadiannamini, P., JoannisCassan, C., Albasi, C., ... Vankelecom, I. F. J. (2019). Micropollutant rejection of annealed polyelectrolyte multilayer based nanofiltration membranes for treatment of conventionally-treated municipal wastewater. Separation and Purification Technology, 209,

470-481. https:// doi.org/10.1016/j.seppur.2018.07.071 
Ahmad, N. A., Leo, C. P., Ahmad, A. L., \& Ramli, W. K. W. (2015). Membranes with Great Hydrophobicity: A Review on Preparation and Characterization.

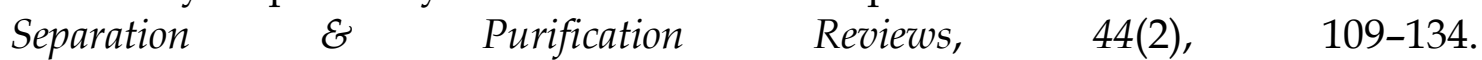
https://doi.org/10.1080/15422119.2013.848816

Azizo, A. S., Wirzal, M. D. H., Bilad, M. R., \& Yusoff, A. R. M. (2017). Assessment of nylon 6, 6 nanofibre membrane for microalgae harvesting. AIP Conference Proceedings, 1891(1), 020032. https:/ / doi.org/10.1063/1.5005365

Balamurugan, R., Sundarrajan, S., \& Ramakrishna, S. (2011). Recent Trends in Nanofibrous Membranes and Their Suitablity for Air and Water Filtrations. 2011(1), 232-248.

Benito, A., Garcia, G., \& Gonzalez-Olmos, R. (2017). Fouling reduction by UV-based pretreatment in hollow fiber ultrafiltration membrane for urban wastewater reuse. Journal of Membrane Science, 536, 141-147.

Bilad, M. R., Azizo, A. S., Wirzal, M. D. H., Jia Jia, L., Putra, Z. A., Nordin, N. A. H. M., ... Yusoff, A. R. M. (2018). Tackling membrane fouling in microalgae filtration using nylon 6,6 nanofiber membrane. Journal of Environmental Management, 223, 23-28. https://doi.org/10.1016/j.jenvman.2018.06.007

Chen, J., Deng, T., Liu, Z., \& Songc, H. (2017). Controllable shrinking of silicon oxide nanopores by high temperature annealing. 2017 China Semiconductor Technology International Conference (CSTIC), 1-3. https:// doi.org/10.1109/CSTIC.2017.7919879

Eliseus, A., Bilad, M. R., Nordin, N. A. H. M., Putra, Z. A., \& Wirzal, M. D. H. (2017). Tilted membrane panel: A new module concept to maximize the impact of air bubbles for membrane fouling control in microalgae harvesting. Bioresource Technology, 241(Supplement $\quad$ C), 661-668. https://doi.org/10.1016/j.biortech.2017.05.175

Foong, C. Y., Wirzal, M. D. H., \& Bustam, M. A. (2019). A review on nanofibers membrane with amino-based ionic liquid for heavy metal removal. Journal of Molecular Liquids, 111793. https:/ / doi.org/10.1016/j.molliq.2019.111793

Hemra, K., Kitiwan, M., \& Atong, D. (2011). Effects of Annealing Conditions on Morphology and Permeability of Palladium Membrane. Materials Science Forum, 695. https://doi.org/10.4028/www.scientific.net/MSF.695.25

Ibrahim, N. A., Wirzal, M. D. H., Nordin, N. A. H., \& Halim, N. S. A. (2018). Development of Polyvinylidene fluoride (PVDF)-ZIF-8 Membrane for Wastewater Treatment. IOP Conference Series: Earth and Environmental Science, 140(1), 012021. https:/ / doi.org/10.1088/1755-1315/140/1/012021

Jiříček, T., Komárek, M., \& Lederer, T. (2017). Polyurethane Nanofiber Membranes for Waste Water Treatment by Membrane Distillation [Research article]. https://doi.org/10.1155/2017/7143035

Kusworo, T. D., Aryanti, N., Firdaus, M. M. H., \& Sukmawati, H. (2015). Surface modification of cellulose acetate membrane using thermal annealing to enhance produced water treatment. AIP Conference Proceedings, 1699(1), 040014. https:// doi.org/10.1063/1.4938329

Li, L., Hashaikeh, R., \& Arafat, H. A. (2013). Development of eco-efficient microporous membranes via electrospinning and annealing of poly (lactic acid). 
Journal of Membrane Science, 436, 57-67. https:/ / doi.org/10.1016/j.memsci.2013.02.037

Mat Nawi, N. I., Abd Halim, N. S., Lee, L. C., Wirzal, M. D. H., Bilad, M. R., Nordin, N. A. H., \& Putra, Z. A. (2020). Improved Nylon 6,6 Nanofiber Membrane in A Tilted Panel Filtration System for Fouling Control in Microalgae Harvesting. Polymers, 12(2), 252. https:/ / doi.org/10.3390/polym12020252

Mohd, A. T., Abd Halim, N. S., Wirzal, M. D. H., Bilad, M. R., Md. Nordin, N. A. H., Adi Putra, Z., \& Mohd Yusoff, A. R. (2020). EFFECT OF BMIM-CHLORIDE ON PHYSIO CHEMICAL PROPERTIES OF NANOFIBER MEMBRANE FOR DOMESTIC WASTEWATER TREATMENT (Kesan BMIM-Klorida ke atas SifatSifat Fisio-Kimia Membran Nanogentian untuk Rawatan Sisa Air Domestik). Malaysian Journal of Analytical Sciences, 24, 78-86.

Saad, M. S., Balasubramaniam, L., Wirzal, M. D. H., Abd Halim, N. S., Bilad, M. R., Md Nordin, N. A. H., ... Ramli, F. N. (2020). Integrated MembraneElectrocoagulation System for Removal of Celestine Blue Dyes in Wastewater. Membranes, 10(8), 184. https:/ / doi.org/10.3390/membranes10080184

Saad, M. S., Wirzal, M. D. H., Abd Halim, N. S., \& Khar, M. R. (2020). Removal color from Palm Oil Mill Effluent (POME): Electrocoagulation Method vs Microfiltration using Nanofiber Membrane. International Journal of Electrochemical Science, 11283-11293. https:/ / doi.org/10.20964/2020.11.08

Sun, Y., Bai, Y., Jiayu, T., Zhiwei, Z., \& Fuyi, C. (2017). Seawater-driven forward osmosis for direct treatment of municipal wastewater. Membrane Water Treatment, 8(5). Retrieved from http://www.iasem.org/publication_conf/acem16/4.AMWT16/M4E.9.MW272_0518F3.pdf

Tan, E. P. S., \& Lim, C. T. (2006). Effects of annealing on the structural and mechanical properties of electrospun polymeric nanofibres. Nanotechnology, 17(10), 26492654. https://doi.org/10.1088/0957-4484/17/10/034

Wang, Z., Cai, N., Dai, Q., Li, C., Hou, D., Luo, X., ... Yu, F. (2014). Effect of thermal annealing on mechanical properties of polyelectrolyte complex nanofiber membranes. Fibers and Polymers, 15(7), 1406-1413. https:// doi.org/10.1007/s12221-014-1406-2

Zhang, J., Liu, H., Ding, J.-X., Zhuang, X.-L., Chen, X.-S., \& Li, Z.-M. (2015). Annealing regulates the performance of an electrospun poly( $\varepsilon$-caprolactone) membrane to accommodate tissue engineering. RSC Advances, 5(41), 32604-32608. https://doi.org/10.1039/C5RA05530J

Zhang, L., Liu, L. G., Pan, F. L., Wang, D. F., Pan, Z. J., \& Zhang, L. (2012). Effects of heat treatment on the morphology and performance of PSU electrospun nanofibrous membrane. Journal of Engineered Fibers and Fabrics, 7(3), 7-16.

Zhang, Lu, Liu, L., Pan, F., Wang, D., \& Pan, Z. (2012). Effects of Heat Treatment on the Morphology and Performance of PSU Electrospun Nanofibrous Membrane. Journal of Engineered Fibers and Fabrics, 7(2_suppl), 155892501200702502. https://doi.org/10.1177/155892501200702S02 